\title{
Structural changes induced by high-pressure processing in micellar casein and milk protein concentrates
}

\author{
Lee Cadesky, ${ }^{*}$ Markus Walkling-Ribeiro, ${ }^{*}$ Kyle T. Kriner, ${ }^{*}$ Mukund V. Karwe, $†$ and Carmen I. Moraru* ${ }^{* 1}$ \\ *Department of Food Science, Cornell University, Ithaca, NY 14853 \\ †Department of Food Science, Rutgers University, New Brunswick, NJ 08901
}

\section{ABSTRACT}

Reconstituted micellar casein concentrates and milk protein concentrates of 2.5 and $10 \%$ (wt/vol) protein concentration were subjected to high-pressure processing at pressures from 150 to $450 \mathrm{MPa}$, for $15 \mathrm{~min}$, at ambient temperature. The structural changes induced in milk proteins by high-pressure processing were investigated using a range of physical, physicochemical, and chemical methods, including dynamic light scattering, rheology, mid-infrared spectroscopy, scanning electron microscopy, proteomics, and soluble mineral analyses. The experimental data clearly indicate pressure-induced changes of casein micelles, as well as denaturation of serum proteins. Calcium-binding $\alpha_{\mathrm{S}^{-}}$and $\alpha_{\mathrm{S} 2^{-}}$-casein levels increased in the soluble phase after all pressure treatments. Pressurization up to $350 \mathrm{MPa}$ also increased levels of soluble calcium and phosphorus, in all samples and concentrations, whereas treatment at 450 MPa reduced the levels of soluble $\mathrm{Ca}$ and P. Experimental data suggest dissociation of calcium phosphate and subsequent casein micelle destabilization as a result of pressure treatment. Treatment of $10 \%$ micellar casein concentrate and $10 \%$ milk protein concentrate samples at $450 \mathrm{MPa}$ resulted in weak, physical gels, which featured aggregates of uniformly distributed, casein substructures of 15 to $20 \mathrm{~nm}$ in diameter. Serum proteins were significantly denatured by pressures above $250 \mathrm{MPa}$. These results provide information on pressure-induced changes in high-concentration protein systems, and may inform the development on new milk protein-based foods with novel textures and potentially high nutritional quality, of particular interest being the soft gel structures formed at high pressure levels.

Key words: high-pressure processing, micellar casein concentrate, milk protein concentrate, pressure-induced milk protein gel

Received September 29, 2016.

Accepted April 7, 2017.

${ }^{1}$ Corresponding author: cim24@cornell.edu
INTRODUCTION

Milk proteins represent the structural basis for dairy foods such as cheese and yogurt, which largely owe their textural and sensory attributes to the formation of protein networks by heat, $\mathrm{pH}$, enzymatic modification, or a combination of these (Farrell, 1999). Highpressure processing (HPP) has emerged in recent years as a nonthermal processing technique able to inactivate microorganisms in foods, and also able to alter the structure and functionality of proteins, including milk proteins. High-pressure-processing-induced physicochemical changes in dairy systems include reduced turbidity, color, and particle size in milk (Gaucheron et al., 1997; Anema et al., 2005b; Orlien et al., 2006), increased viscosity in concentrated milks (Merel-Rausch et al., 2006), and altered rennet and acid coagulation kinetics and coagulum properties (Anema et al., 2005a; Zobrist et al., 2005). Most of the research on pressureinduced changes in milk proteins has been conducted at naturally occurring, low protein concentrations. Such changes could, however, open interesting opportunities in high-concentration protein systems, where HPP treatment may facilitate the creation of unique structures and functionalities. In this context, it becomes very interesting to explore the effect of HPP treatment on commercially available milk protein concentrates, such as milk protein concentrate (MPC) and micellar casein concentrate (MCC). Due to the strong interest in food products with a high protein content, both MPC and MCC have become increasingly available and used in recent years. Although these dairy ingredients offer nutritional and functional benefits compared with other protein sources, their utilization is still largely limited to traditional uses, such as protein fortification of cheese or yogurt.

The hypothesis of this work was that high-pressure treatment of high-protein-concentration systems will enable the formation of unique structures, without the use of heat or chemical additives. The outcome of the treatment may be different for MCC compared with $\mathrm{MPC}$, due to the different level of serum proteins in the 
Table 1. Casein and calcium concentrations in the micellar casein concentrate (MCC) and milk protein concentrate (MPC) preparations

\begin{tabular}{lccc}
\hline Sample & Protein level/sample code $(\%)$ & Actual casein concentration $(\mathrm{g} / 100 \mathrm{~g})$ & Total calcium concentration $(\mathrm{mg} / \mathrm{g})$ \\
\hline MCC, untreated & 2.50 & 2.29 & 0.61 \\
& 10 & 8.38 & 2.22 \\
MPC, untreated & 2.50 & 1.93 & 0.54 \\
& 10 & 7.08 & 1.99 \\
\hline
\end{tabular}

2 types of protein ingredients. Therefore, the objective of this study was to investigate the effect of HPP treatments at pressures between 150 and $450 \mathrm{MPa}$ on MCC and MPC, at both low and high protein concentration. The results of this research further the understanding of pressure-induced changes in concentrated protein systems and also provide a basis for the development of milk-protein-based products with novel structures and textures.

\section{MATERIALS AND METHODS}

\section{Protein Concentrates}

Commercial MCC $(83.53 \mathrm{~g} / 100 \mathrm{~g}$ of total protein, $71.00 \mathrm{~g} / 100 \mathrm{~g}$ of casein, $2.00 \mathrm{~g} / 100 \mathrm{~g}$ of fat, $0.50 \mathrm{~g} / 100$ $\mathrm{g}$ of lactose, $9.00 \mathrm{~g} / 100 \mathrm{~g}$ of ash, $1.88 \mathrm{~g} / 100 \mathrm{~g}$ of total calcium, and $5 \mathrm{~g} / 100 \mathrm{~g}$ of moisture) and MPC (81.00 $\mathrm{g} / 100 \mathrm{~g}$ of total protein, $63.76 \mathrm{~g} / 100 \mathrm{~g}$ of casein, 2.00 $\mathrm{g} / 100 \mathrm{~g}$ of fat, $6.00 \mathrm{~g} / 100 \mathrm{~g}$ of lactose, $4.50 \mathrm{~g} / 100 \mathrm{~g}$ of ash, $1.79 \mathrm{~g} / 100 \mathrm{~g}$ of calcium, and $5 \mathrm{~g} / 100 \mathrm{~g}$ of moisture) powders were obtained from the American Casein Company (AMCO, Burlington, NJ).

The casein to serum protein ratio, calculated based on the total protein and casein concentrations, was 85:15 in MCC and 79:21 in MPC (same as in skim milk). The protein powders were reconstituted with deionized (DI) water to produce suspensions with target protein concentrations of 2.5 and $10 \%$ (weight basis), respectively. The actual casein and calcium concentrations of the suspensions are shown in Table 1.

\section{Protein Sample Preparation}

The suspensions were stirred at $500 \mathrm{rpm}$ and $25^{\circ} \mathrm{C}$ for $30 \mathrm{~min}$. After that, $100 \mathrm{~mL}$ of suspension was highshear-mixed using an Ultraturrax T25 batch disperser equipped with the S25N-18G fixture (IKA Works Inc., Wilmington, NC) for $7.5 \mathrm{~min}$, at 21,500 rpm. The resulting suspensions were then stirred at $400 \mathrm{rpm}$ and $25^{\circ} \mathrm{C}$ for another $90 \mathrm{~min}$ to enable full hydration and settling of foam. Finally, 50-mL aliquots were filled in vacuum storage bags (Seal-a-Meal, Sunbeam Products Inc., Boca Raton, FL) and double-sealed using a vacuum sealer (AGW Multivac, Sepp Haggenmüller KG, Wolfertsschwenden, Germany). The packaged MCC and MPC samples were stored overnight at $4^{\circ} \mathrm{C}$ before HPP treatment.

\section{HPP Treatment}

The protein samples were processed using a 10-L HPP unit (Elmhurst Research Inc., Albany, NY) located at the Department of Food Science at Rutgers University (New Brunswick, NJ). Samples were subjected to pressure treatments at $150,250,350$, and $450 \mathrm{MPa}$ for a holding time of $15 \mathrm{~min}$. Initial and maximum temperatures of the pressurizing medium (filtered water), as well as pressurization and depressurization rates are shown in Table 2.

\section{Composition Analyses}

The chemical composition of the samples was determined at Dairy One Laboratory (Ithaca, NY). Lactose content was determined by infrared spectroscopy (Lactoscope FTIR, Delta Instruments, Drachten, the Netherlands), the fat content by ether extraction (method 989.05; AOAC International, 2010a), and the total nitrogen by the Kjeldahl method (method 991.20; AOAC International, 2010b). The NPN was determined by Kjeldahl method (method 991.21; AOAC International, 2010b), and the noncasein nitrogen also by the Kjeldahl method (method 998.05; AOAC International, 2010c).

Table 2. Temperature and pressure data for the pressure treatments

\begin{tabular}{|c|c|c|c|c|c|}
\hline $\begin{array}{l}\text { Treatment pressure } \\
\text { level }(\mathrm{MPa})\end{array}$ & $\begin{array}{l}\text { Initial temperature } \\
\qquad\left({ }^{\circ} \mathrm{C}\right)\end{array}$ & $\begin{array}{l}\text { Maximum temperature } \\
\left({ }^{\circ} \mathrm{C}\right)\end{array}$ & $\begin{array}{c}\text { Maximum } \\
\text { pressure }(\mathrm{MPa})\end{array}$ & $\begin{array}{l}\text { Pressurization rate } \\
(\mathrm{MPa} / \mathrm{s})\end{array}$ & $\begin{array}{c}\text { Depressurization rate } \\
(\mathrm{MPa} / \mathrm{s})\end{array}$ \\
\hline 150 & $14.6 \pm 4.5$ & $18.3 \pm 2.6$ & $158.1 \pm 2.9$ & $2.4 \pm 0.2$ & $35.1 \pm 4.6$ \\
\hline 250 & $14.8 \pm 3.4$ & $20.2 \pm 2.6$ & $261.6 \pm 2.0$ & $2.8 \pm 0.1$ & $51.4 \pm 0.6$ \\
\hline 350 & $14.7 \pm 4.9$ & $21.4 \pm 1.8$ & $360.6 \pm 0.7$ & $3.1 \pm 0.1$ & $71.2 \pm 0.7$ \\
\hline 450 & $13.7 \pm 5.5$ & $22.3 \pm 2.0$ & $463.6 \pm 2.4$ & $3.1 \pm 0.1$ & $84.4 \pm 7.8$ \\
\hline
\end{tabular}


The calcium content was determined using a Thermo Jarrell Ash IRIS Advantage HX inductively coupled plasma radial spectrophotometer (Thermo Scientific, Madison, WI). Moisture content was determined by oven drying (method 927.05; AOAC International, 2010d).

\section{Soluble Protein and Mineral Analyses}

Pressure-treated and untreated protein samples were analyzed for soluble proteins and minerals. For this, samples were centrifuged at $290,000 \times g$ at the average radius of the rotor $(61.2 \mathrm{~mm})$, for $35 \mathrm{~min}$ at room temperature (approximately $20^{\circ} \mathrm{C}$ ), in a Beckman L8-70MR ultracentrifuge (Beckman Coulter, Pasadena, CA) fitted with a Ti 70.1 rotor. The supernatant obtained from ultracentrifugation was subjected to protein and mineral analyses, as described below.

Proteomic Analyses. Protein analysis of the supernatants of the treated and untreated protein samples was performed using the method developed by Sauer and Moraru (2012). First, supernatant samples were tested for protein content using the Bradford assay, using BSA as a standard, according to the manufacturer's instructions (Thermo Fisher Scientific, Waltham, MA). A volume containing $10 \mu \mathrm{g}$ of protein was then transferred to a $0.6-\mathrm{mL}$ microcentrifuge tube and freezedried using a FreeZone 4.5-L freeze dryer (Labconco, Kansas City, MO). Dry samples were resuspended and denatured using $20 \mu \mathrm{L}$ of buffer containing $3 M$ guanidine hydrochloride and $10 \mathrm{~m} M$ dithiothreitol in $50 \mathrm{~m} M$ Tris- $\mathrm{HCl}$, incubated at $55^{\circ} \mathrm{C}$, for $1 \mathrm{~h}$. Unless otherwise specified, all reagents were purchased from Thermo Fisher Scientific. Samples were then cooled to room temperature and cysteine residues alkylated by adding $2.2 \mu \mathrm{L}$ of freshly prepared $0.6 M$ iodoacetamide in $50 \mathrm{~m} M$ Tris- $\mathrm{HCl}$ buffer to each sample. Samples were then stored in the dark at room temperature for $1 \mathrm{~h}$. The reaction was quenched by adding $2.5 \mu \mathrm{L}$ of $0.2 \mathrm{M}$ dithiothreitol in Milli-Q water, followed by incubation at room temperature for $10 \mathrm{~min}$. To prepare for trypsin digestion, the sample $\mathrm{pH}$ was increased by adding 175 $\mu \mathrm{L}$ of $50 \mathrm{~m} M$ ammonium bicarbonate dissolved in Milli$\mathrm{Q}$ water. Finally, $20 \mu \mathrm{g}$ of sequencing grade porcine trypsin (Promega, Madison, WI) was resuspended in $200 \mu \mathrm{L}$ of Milli-Q water, and $5 \mu \mathrm{L}$ of the suspension added to each sample. Samples were incubated for 16 $\mathrm{h}$ at $37^{\circ} \mathrm{C}$, after which trypsin digestion was stopped by adding $2 \mu \mathrm{L}$ of $98 \%$ formic acid to each sample. Digested samples were stored at $-20^{\circ} \mathrm{C}$ until analyzed by liquid chromatography multiple reaction monitoring by the Cornell Proteomics and Mass Spectroscopy Facility (Ithaca, NY).
Soluble Mineral Analyses. Soluble mineral analyses were performed by the Dairy One Laboratory (Ithaca, NY). Five grams of the supernatant was weighed and placed in a CEM Microwave Accelerated Reaction System digestion vessel (CEM Corporation, Matthews, NC) with $8 \mathrm{~mL}$ of concentrated nitric acid and $2 \mathrm{~mL}$ of concentrated hydrochloric acid, and then digested at $1,600 \mathrm{~W}$ and $190^{\circ} \mathrm{C}$ for $30 \mathrm{~min}$ ( 15 min come-up time and 15 min holding time). The calcium, phosphorus, magnesium, potassium, and sodium content of the supernatant was analyzed using a Thermo ICAP 6300 inductively coupled plasma radial spectrophotometer (Thermo Fisher Scientific).

\section{Concentration of lonic Calcium}

The concentration of free $\mathrm{Ca}^{2+}$ in the $10 \% \mathrm{MCC}$ and $10 \%$ MPC, before and after HPP treatment, was measured using an Accumet AR10 (Fisher Scientific, Pittsburgh, PA) fitted with a Calcium ionplus Sure-Flow Plastic Membrane Combination ISE electrode (model 9720BNWP, Thermo Fisher Scientific). Calibration of the calcium electrode was performed using calcium calibration standards of 10 and $1,000 \mathrm{mmol} / \mathrm{kg}$ concentration, immediately before the measurements.

\section{Evaluation of Protein Denaturation}

Denaturation of whey proteins in MCC and MPC was evaluated using attenuated total reflectance (ATR) Fourier transformed infrared spectroscopy (FTIR). The ATR-FTIR data were collected using a Shimadzu IRAffinity-1S Fourier Transform Infrared Spectrometer (Shimadzu Corp., Kyoto, Japan), equipped with a Quest ATR Diamond Accessory (Specac Inc., Swedesboro, NJ) and Lab Solutions IR integrated software. The HTST pasteurized skim milk was used as negative control, and skim milk subjected to heating for more than 5 min at a temperature between 90 and $95^{\circ} \mathrm{C}$ was used as a positive control. Deionized water, MPC, and MCC spectra were collected in absorbance mode with Happ-Genzel apodization. For each sample, an average of 128 scans were recorded at a high-resolution setting of $0.5 \mathrm{~cm}^{-1}$ in the range of 400 to $4,000 \mathrm{~cm}^{-1}$ with background subtraction. Final MPC and MCC spectral data were smoothed using a 64-point absorbance averaging function, and then corrected by subtracting the infrared spectrum of DI water measured on the same day, under identical conditions.

\section{Rheological Analyses}

Small-amplitude, dynamic strain sweep tests were performed for all MCC and MPC samples, using an 
ARES strain-controlled rheometer (TA Instruments, New Castle, DE). A parallel plate geometry with 50$\mathrm{mm}$ diameter Teflon plates and an interplaten gap of 1 $\mathrm{mm}$ were used. Measurements were conducted at a frequency of $1 \mathrm{rad} / \mathrm{s}$ and a temperature of $4^{\circ} \mathrm{C}$, which was maintained using a Peltier temperature control system. An isothermal chamber was used to enclose the geometry, which helped maintain a constant temperature and prevent sample dehydration during the tests. Previously refrigerated samples were gently handled and loaded onto the rheometer test geometry, to prevent the disruption of any existing structure. A relaxation period of 1 min was allowed after the sample reached the test temperature of $4^{\circ} \mathrm{C}$. The linear viscoelastic region was identified for all samples, and the values of the elastic modulus $\left(\mathbf{G}^{\prime}\right)$, loss modulus $\left(\mathbf{G}^{\prime \prime}\right)$, and loss tangent ( $\tan \boldsymbol{\delta}=\mathrm{G}^{\prime \prime} / \mathrm{G}^{\prime}$ ) in the linear viscoelastic region were used to make direct comparisons among samples. All rheological measurements were performed in triplicate.

\section{Renneting Behavior of HPP-Treated Samples}

To investigate the structural changes of casein micelles induced by HPP, an enzymatic coagulation study of the protein samples was conducted. It is important to specify that the physical structure formed as a result of HPP treatment was disrupted by shear during the sample preparation in the renneting study. Changes that occurred during renneting were evaluated by rheology and particle size analyses.

Assessment of Renneting Behavior by Rheological Analysis. Changes in sample firmness, as expressed by $\mathrm{G}^{\prime}$, were used as an indication of network formation following the addition of rennet. Rheological measurements were conducted using an ARES Rheometer (TA Instruments) fitted with a 50-mm parallel plate and a Peltier water bath. To prevent slippage, 120-grit sandpaper of the same diameter as the parallel plate was affixed to the top and bottom plates. One hundred microliters of the diluted rennet was added to 5 -mL protein samples while stirring on a vortex mixer. To prevent enzymatic action before the start of rheological testing, rennet was added to the samples at $4^{\circ} \mathrm{C}$. The rheometer plate was also maintained at $4^{\circ} \mathrm{C}$ until the sample was loaded and ready for testing. Approximately $1.75 \mathrm{~mL}$ of renneted sample was used for each rheological test. The edge of the loaded sample was coated with a thin layer of mineral oil and a moistened enclosure was placed around the test fixture to prevent dehydration during testing. Once the sample was loaded, the temperature was raised to $36^{\circ} \mathrm{C}$. A $30-\mathrm{s}$ delay was allowed before the start of the test for the sample temperature to equilibrate. Time sweeps were performed at a frequency of $1 \mathrm{~Hz}$ and $1 \%$ strain (which was determined to be in the linear viscoelastic region of all samples), and a 0.5 -mm interplate gap. Time sweeps were replicated 5 times for each sample.

Analysis of Particle Size During Renneting. Particle size during renneting was evaluated using a 90Plus Nanoparticle particle size analyzer (Brookhaven Instruments Corp., Holtsville, NY), equipped with a Peltier temperature control system, at a fixed $90^{\circ}$ angle and a wavelength of $658 \mathrm{~nm}$. Average particle size and particle size distributions were determined using the instrument's software (Brookhaven Instruments Corp., Holtsville, NY). Before analysis, samples were diluted 10 times, by volume, in DI water, to ensure a signal intensity between 400 and $600 \mathrm{kcounts} / \mathrm{s}$, as recommended by the manufacturer. To analyze particle size evolution during renneting, a 5 -mL aliquot and a reservoir of DI water were warmed to $36^{\circ} \mathrm{C}$ and held for 30 min in a water bath (Isotemp 220, Thermo Fisher Scientific). A volume of $100 \mu \mathrm{L}$ of ChyMax-M microbial rennet, diluted 400 times in DI water, was added to the 5 -mL sample while stirring on a vortex mixer (Thermo Fisher Scientific) at 1,250 rpm for $30 \mathrm{~s}$. The sample was maintained at $36^{\circ} \mathrm{C}$ in the water bath for $1 \mathrm{~h}$ after renneting. A $30-\mu \mathrm{L}$ subsample was diluted with warm DI water in a cuvette with $10-\mathrm{mm}$ path length, then promptly analyzed for particle size at $36^{\circ} \mathrm{C}$. Samples were analyzed every $5 \mathrm{~min}$, for $1 \mathrm{~h}$, unless they were visibly coagulated as indicated by the presence of visible flocks in the cuvette. Measurements for each experimental condition were performed in triplicate.

\section{Structural Analyses by Scanning Electron Microscopy}

Droplets of untreated and pressure-treated MCC and MPC samples, respectively, were deposited onto a glass slide and subjected to air drying. Samples were fixed by $2.5 \%$ (wt/vol) glutaraldehyde in $0.05 \mathrm{M}$ sodium cacodylate buffer for $1 \mathrm{~h}$, rinsed in cacodylate buffer 3 times, for 5 min each, then fixed by a secondary fixation step using 1\% (wt/vol) osmium tetroxide in cacodylate buffer, for $30 \mathrm{~min}$. Samples were then rinsed again in cacodylate buffer 3 times, and dehydrated using gradient ethanol solutions of 25, 50, 70, 95, 100, and $100 \%$ (vol/vol), for 10 min each. Samples in $100 \%$ ethanol were critical point-dried with carbon dioxide. Dried surfaces were mounted with carbon tape to scanning electron microscopy stubs and coated with evaporated carbon. A Zeiss LEO 1550 field emission scanning electron microscopy (Carl Zeiss Microscopy LLC, Jena, Germany) was used at a voltage of $3 \mathrm{kV}$. Images were acquired using the instrument accompanying software SmartSEM. 


\section{Statistical Analysis}

All experiments were repeated 2 to 5 times, depending on the analysis, and the experimental data were analyzed using ANOVA at a confidence level of $95 \%$, with JMP Pro 10.0.2 (SAS Institute Inc., Cary, NC). Statistical differences were analyzed using Tukey's HSD for multiple pairwise comparisons between means. Differences with $P$-values $<0.05$ were considered statistically significantly different.

\section{RESULTS}

\section{Effect of HPP on Particle Size}

For both MCC and MPC significant changes in particle size $(P<0.05)$ were observed as a result of pressure treatments, but these changes were different for the 2 casein concentrations tested. For the $2.5 \% \mathrm{MCC}$ and $2.5 \%$ MPC samples, increasing pressure resulted in progressively smaller particle sizes (Figure 1). Because the main contributors to the particle size in these protein samples are the casein micelles, a decrease in particle size suggests a disruption of casein micelles with pressure. For the pressure-treated 10\% MCC and 10\% MPC, after a slight decrease in particle size after the
$150 \mathrm{MPa}$ treatment, a statistically significant increase in particle size was observed for treatments at pressure levels above $250 \mathrm{MPa}$. This increase in the particle size suggests aggregation phenomena in the HPP-treated, high-concentration samples, which is consistent with previous reports (Gaucheron et al., 1997; Considine et al., 2007). For $10 \% \mathrm{MCC}$ treated at 350 and $450 \mathrm{MPa}$, and $10 \% \mathrm{MPC}$ treated at $450 \mathrm{MPa}$, visible gelling occurred, and particle size for those particular conditions could not be accurately determined.

\section{Microstructure of HPP-Treated MCC and MPC}

Scanning electron microscopy images of undiluted MCC and MPC samples revealed that the microstructure of the samples was significantly altered by the pressure treatment. Scanning electron microscopy images of untreated samples featured nearly spherical casein micelles, with a diameter in the range of hundreds of nanometers, which appear less clearly defined in MCC (Figure 2) than in MPC (Figure 3). It should be noted that the scanning electron microscopy images reveal the presence of spherical substructures of about $20 \mathrm{~nm}$ in diameter. After pressurization at $150 \mathrm{MPa}$, micelles began to lose their integrity and became smaller and more

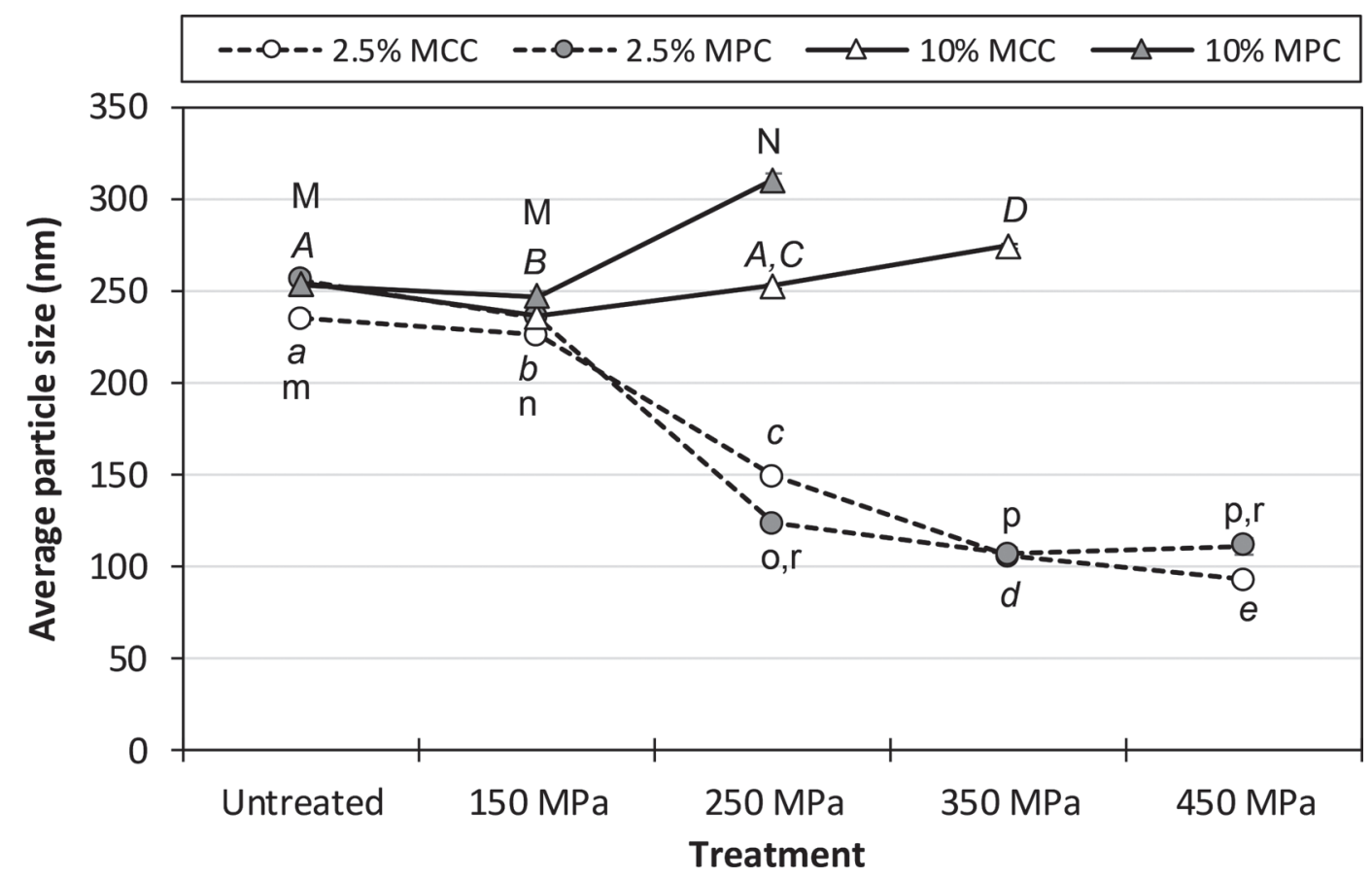

Figure 1. Average particle size for micellar casein concentrates (MCC) and milk protein concentrates (MPC) after pressure treatment, measured at $20^{\circ} \mathrm{C}$. Particle size for $10 \% \mathrm{MCC}$ treated at 350 and $450 \mathrm{MPa}$ and $10 \% \mathrm{MPC}$ treated at $450 \mathrm{MPa}$ could not be accurately measured due to network formation. Data points represent averages of 6 measurements for MCC and 4 measurements for MPC. Error bars represent SEM. Within the same type of sample, treatments without the same letter are significantly different from each other $(P<0.05)$. Letters are used as follows: $2.5 \%$ MCC: a-e; $2.5 \%$ MPC: m-r; $10 \%$ MCC: A-D; $10 \%$ MPC: M, N. 

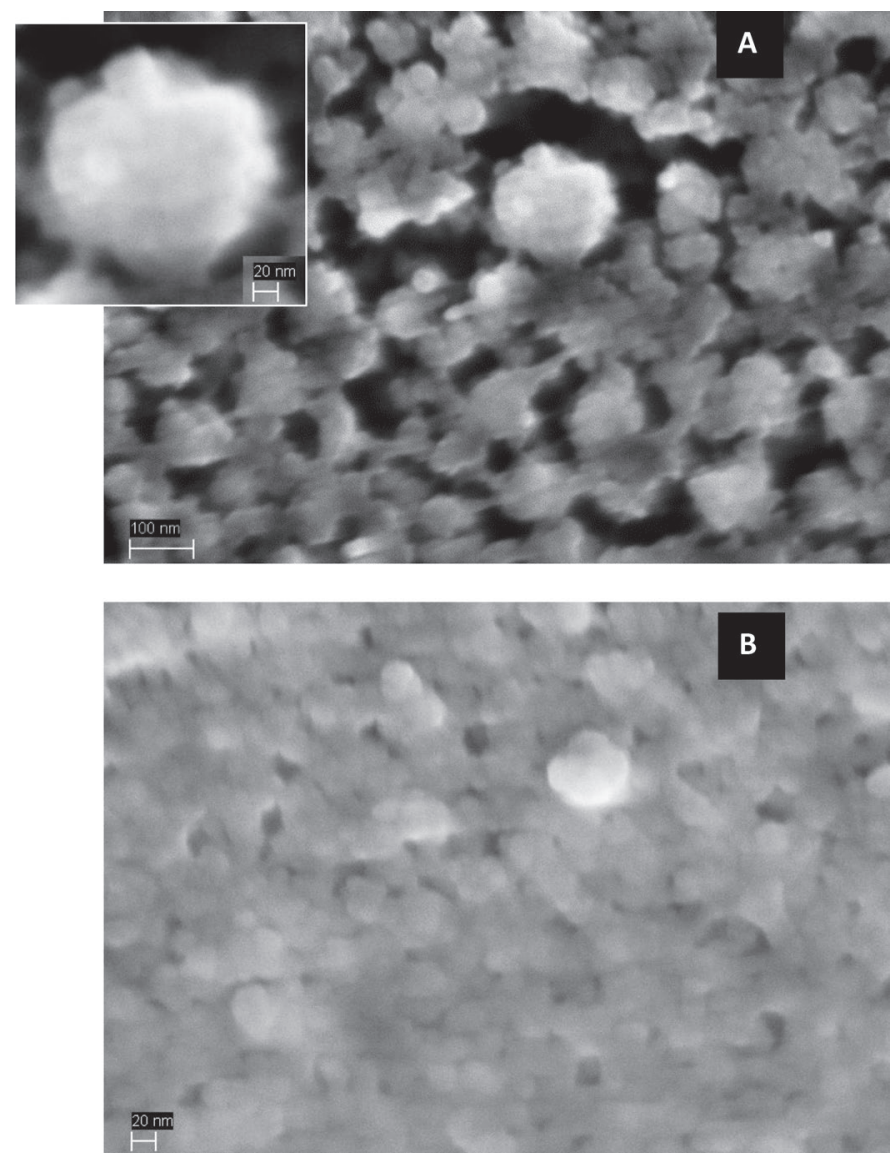

Figure 2. Scanning electron micrographs of $10 \%$ micellar casein concentrates (MCC): (A) untreated, and (B) treated at $450 \mathrm{MPa}$. The inserts show close-up images of casein micelles.

irregularly shaped (Figure 2B). This is consistent with observations from Huppertz et al. (2003), who reported altered micelle size after pressure treatment at 100 to $200 \mathrm{MPa}$. Scanning electron microscopy images of $10 \%$ $\mathrm{MCC}$ and 10\% MPC treated at $450 \mathrm{MPa}$ (Figures 2C and $3 \mathrm{~B}$ ) revealed dense networks of small, spherical aggregates of approximately $20 \mathrm{~nm}$ in diameter.

\section{Effect of HPP Treatment on Rheological Properties of MCC and MPC}

All 2.5\% samples had a liquid-like behavior, with low values of $\mathrm{G}^{\prime}$ and $\mathrm{G}^{\prime \prime}>\mathrm{G}^{\prime}$ for $\mathrm{MPC}$ and $\mathrm{G}^{\prime \prime} \sim \mathrm{G}^{\prime}$ for MCC, which corresponded to $\tan \delta>1$ for $2.5 \%$ MPC and $\tan \delta \sim 1$ for $2.5 \mathrm{MCC}$, respectively (Figure 4 ). The HPP treatment did not affect the rheological properties of any of the low concentration samples, at any pressure level. The untreated $10 \%$ MCC samples had a predominant $\mathrm{G}^{\prime}$ value $(\tan \delta<1$ ), a behavior characteristic for high concentrated dispersions, whereas the untreated 10\% MPC samples had a liquid-like behavior
$\left(\mathrm{G}^{\prime}<\mathrm{G}^{\prime \prime}, \tan \delta>1\right.$; Steffe, 1996). The difference can be explained by the lower casein concentration, which is the highest contributor to sample consistency, and slightly lower total protein in MPC as compared with MCC. Pressure treatments at 350 and $450 \mathrm{MPa}$ resulted in a significant increase in $\mathrm{G}^{\prime}$, by nearly 2 orders of magnitude, as compared with the untreated samples, and a drop in $\tan \delta$ to 0.2 to 0.3 . These values are indicative of a clear solid-like behavior and a weak gellike structure (Steffe, 1996), which is consistent both with the visual and scanning electron microscopy observations, and with previous reports (Keenan et al., 2001; Merel-Rausch et al., 2007).

\section{Effect of HPP on the Renneting Behavior of MCC and MPC}

Renneting behavior was used as an indicator of structural changes that occurred in the $10 \%$ protein concentrates subjected to HPP treatment. In this part of
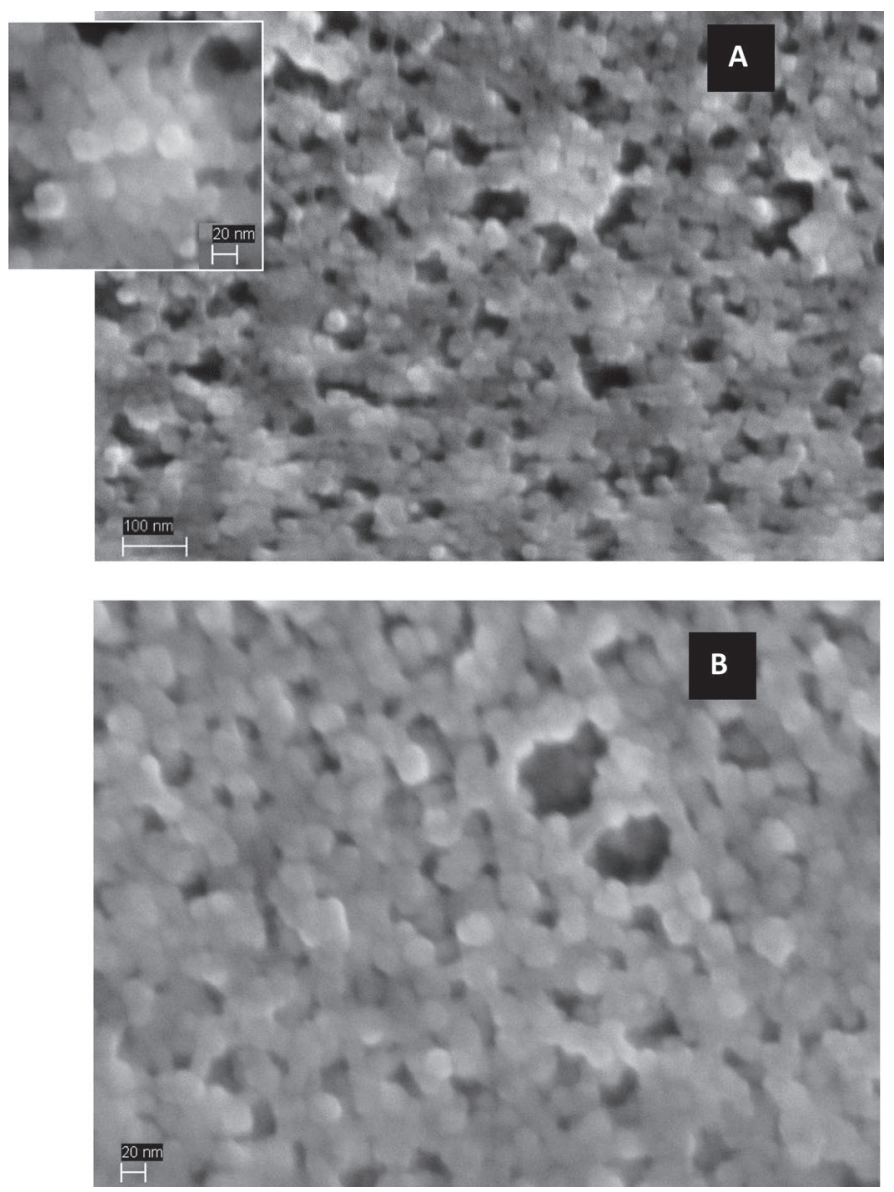

Figure 3. Scanning electron micrographs of $10 \%$ milk protein concentrates (MPC): (A) untreated, and (B) treated at $450 \mathrm{MPa}$. The insert represents a close-up image of a casein micelle. 
the study, all protein samples (untreated and pressure treated) were subjected to shear before adding the rennet, and therefore the discussion in the next paragraph will focus on the observed trends, and not on the actual values of the rheological parameters or particle sizes. The actual particle sizes and rheological characteristics of the MCC and MPC samples are presented in the previous section.
Immediately after adding the rennet, particle size decreased slightly in both 10\% MCC and 10\% MPC, which may be caused by the cleavage of $\kappa$-casein and loss of the GMP fragment into the serum phase. After about $15 \mathrm{~min}$, the particle size started to increase progressively, indicating the beginning of the aggregation process. In $10 \%$ MCC (Figure 5A), pressurization at 150 and $450 \mathrm{MPa}$ resulted in more rapid aggregation
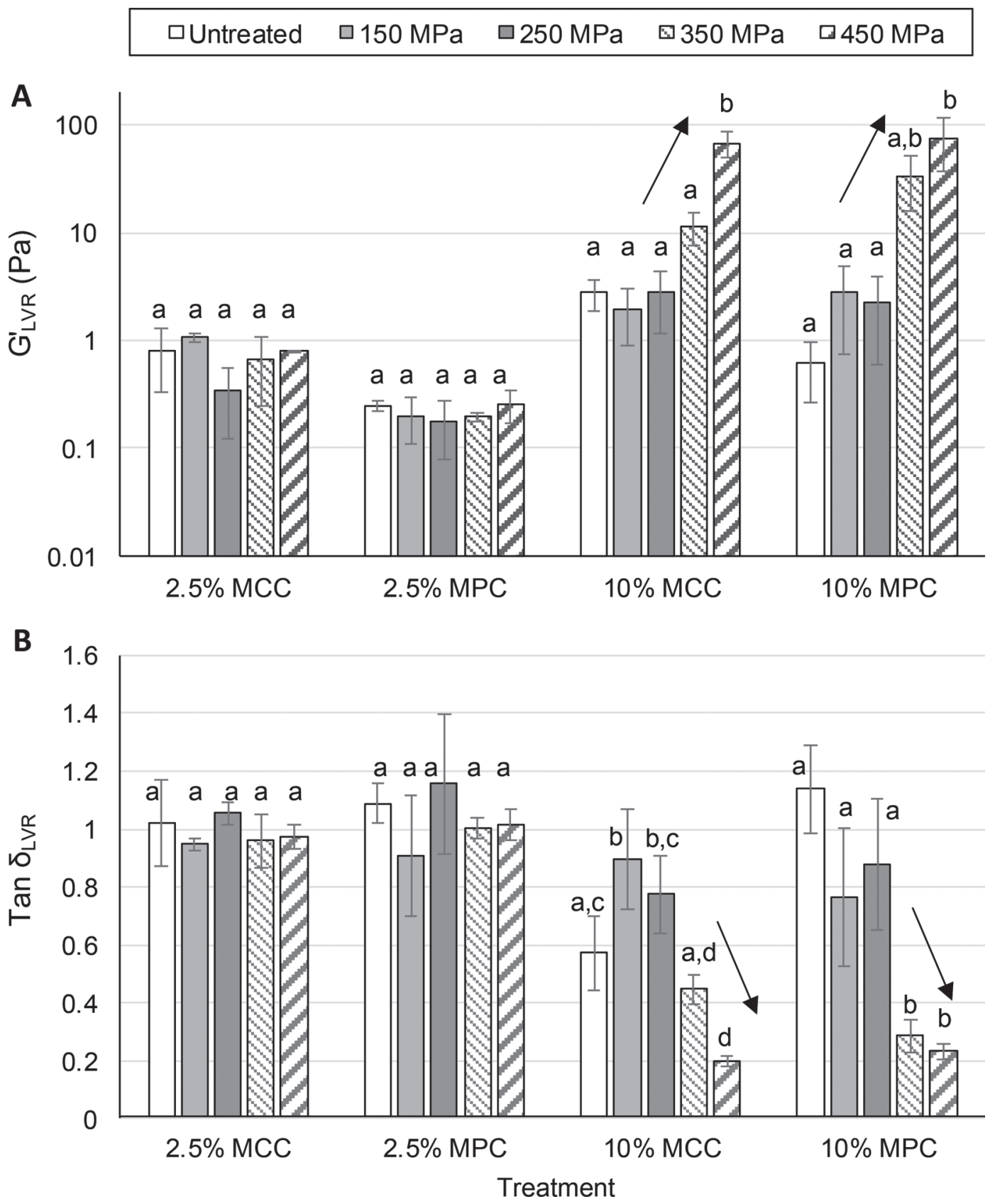

Figure 4. Rheological properties of untreated and high-pressure processing (HPP) treated micellar casein concentrates (MCC) and milk protein concentrates (MPC) in the linear viscoelastic region (LVR). (A) Elastic modulus $\left(\mathrm{G}^{\prime}\right)$; (B) loss factor (tan $\delta$ ). Data points are averages of triplicate measurements, and error bars represent $\pm 1 \mathrm{SD}$. Within the same type of sample, treatments without the same letter are significantly different from each other $(P<0.05)$. Arrows are used to indicate the direction of the change in rheological properties with changes in pressure. 
and larger aggregate sizes compared with the untreated control, whereas treatment at 250 and $350 \mathrm{MPa}$ delayed aggregation and resulted in smaller aggregates compared with the control. In 10\% MPC (Figure 5B), higher pressure levels led to larger particle size and more rapid aggregation compared with the untreated samples. The particle size data matched very well the rheological data. The increase in the elastic modulus $\left(G^{\prime}\right)$ of the samples after the addition of rennet observed in Figure 5 is an indication of network formation.
To quantify the rate and extent of network formation in the different protein samples, the rheological data were fitted with the linearized Scott-Blair model (Scott-Blair and Burnett, 1963; O'Callaghan and Guinee, 1995), shown in Equation [1]:

$$
\ln \left(G^{\prime}\right)=\ln \left(G_{\infty}^{\prime}\right)-\lambda / t
$$

where $G_{\infty}^{\prime}$ is the limiting value of network firmness, at time $t \rightarrow \infty(\mathrm{Pa}), \lambda$ is the time required to reach a $\mathrm{G}^{\prime}$

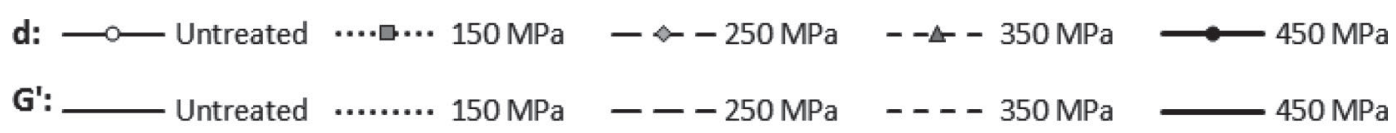

A

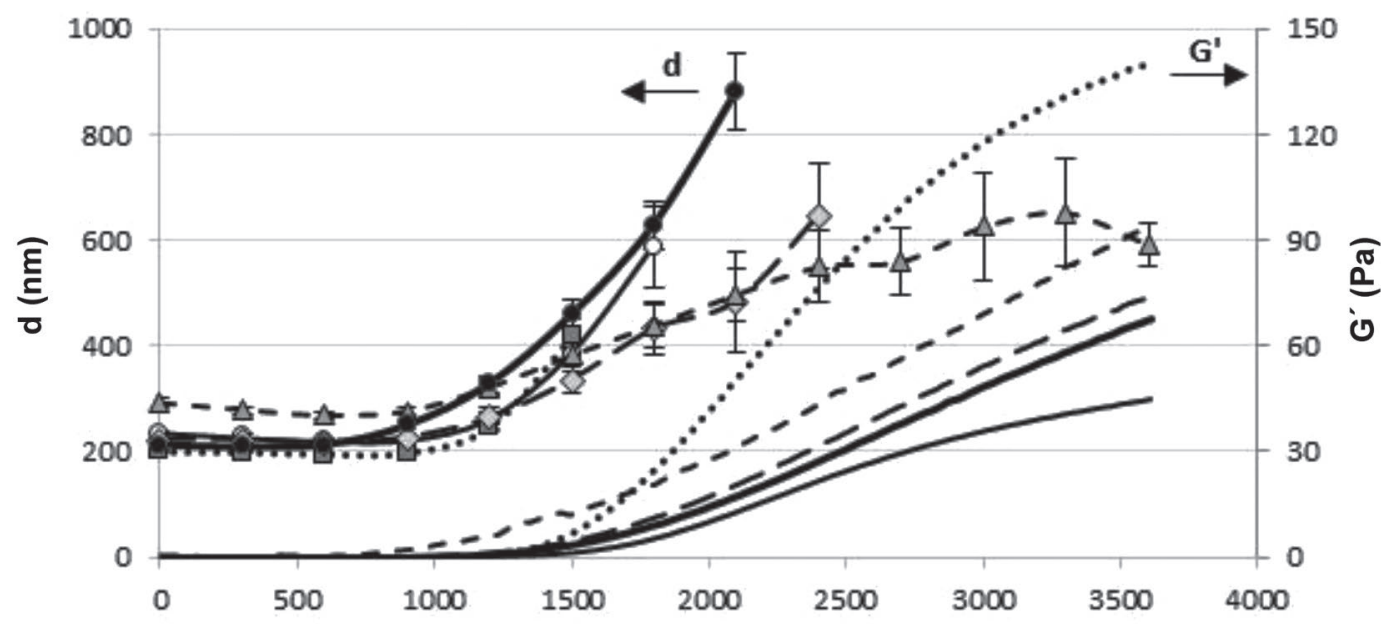

B

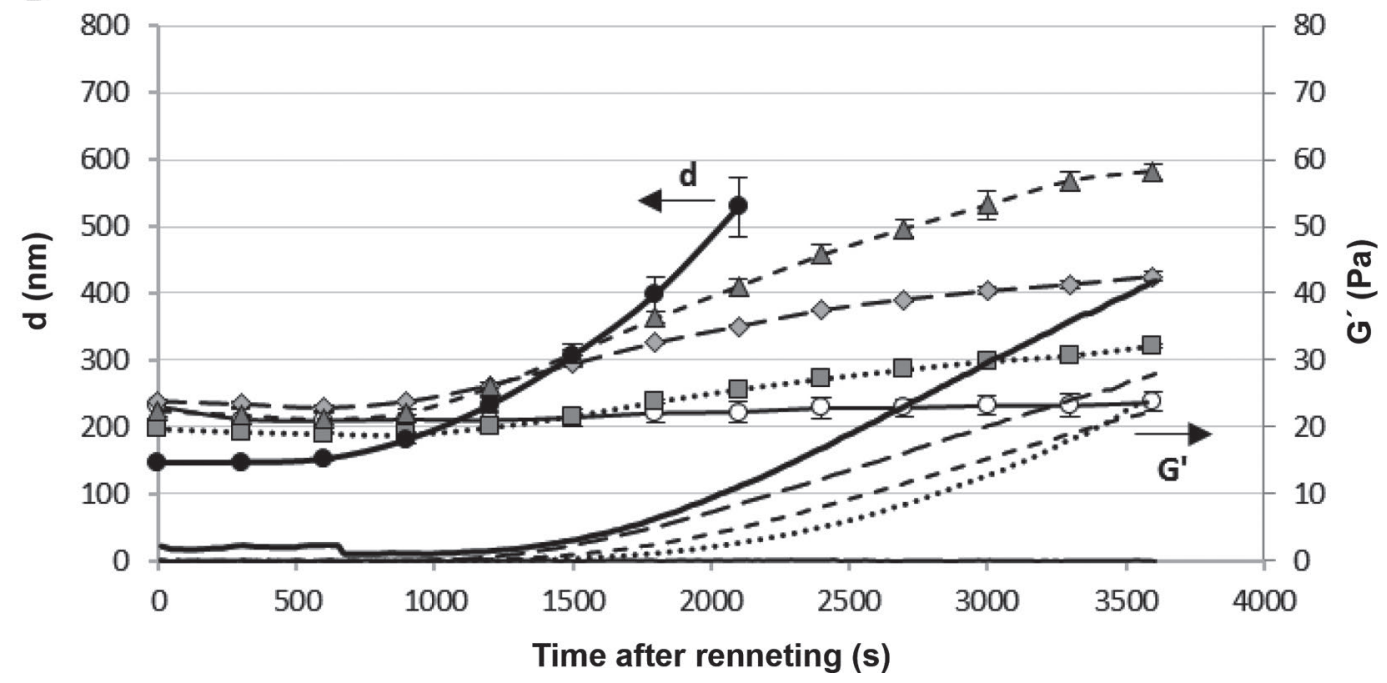

Figure 5. Changes in particle size $\left(\mathrm{d}=\right.$ average particle diameter) and elastic modulus $\left(\mathrm{G}^{\prime}\right)$ values during renneting of pre-sheared untreated and pressure-treated 10\% micellar casein concentrates (MCC; A) and 10\% milk protein concentrates (MPC; B). Particle size measurements were discontinued when visible aggregation of the samples was noticed. $\mathrm{G}^{\prime}$ curves represent averages of 3 replicates. Error bars represent \pm 1 SD. All protein samples were subjected to shear mixing before the addition of rennet. 
value of $G_{\infty}^{\prime} / e(\mathrm{~s})$. Parameters $G_{\infty}^{\prime}$ and $\lambda$ were determined and used to make direct comparisons among samples. A different extent and kinetics of structure formation was observed for the $10 \% \mathrm{MCC}$ and MPC, respectively (Figure 6). In untreated MPC, no coagulation was observed within $60 \mathrm{~min}$ after renneting. Pressure-treated renneted MPC samples showed network formation, with increasing pressure level leading to higher firmness and reduced network formation time. The HPP treatment had no significant effect on the network formation time $(\lambda)$ for $10 \%$ MCC, though slight reductions were observed for the pressure-treated samples, particularly for the 350 and $450 \mathrm{MPa}$ treatments. Firmness was much higher for the renneted HPP treated compared with untreated samples, although the pressure level did not significantly affect $G_{\infty}^{\prime}$
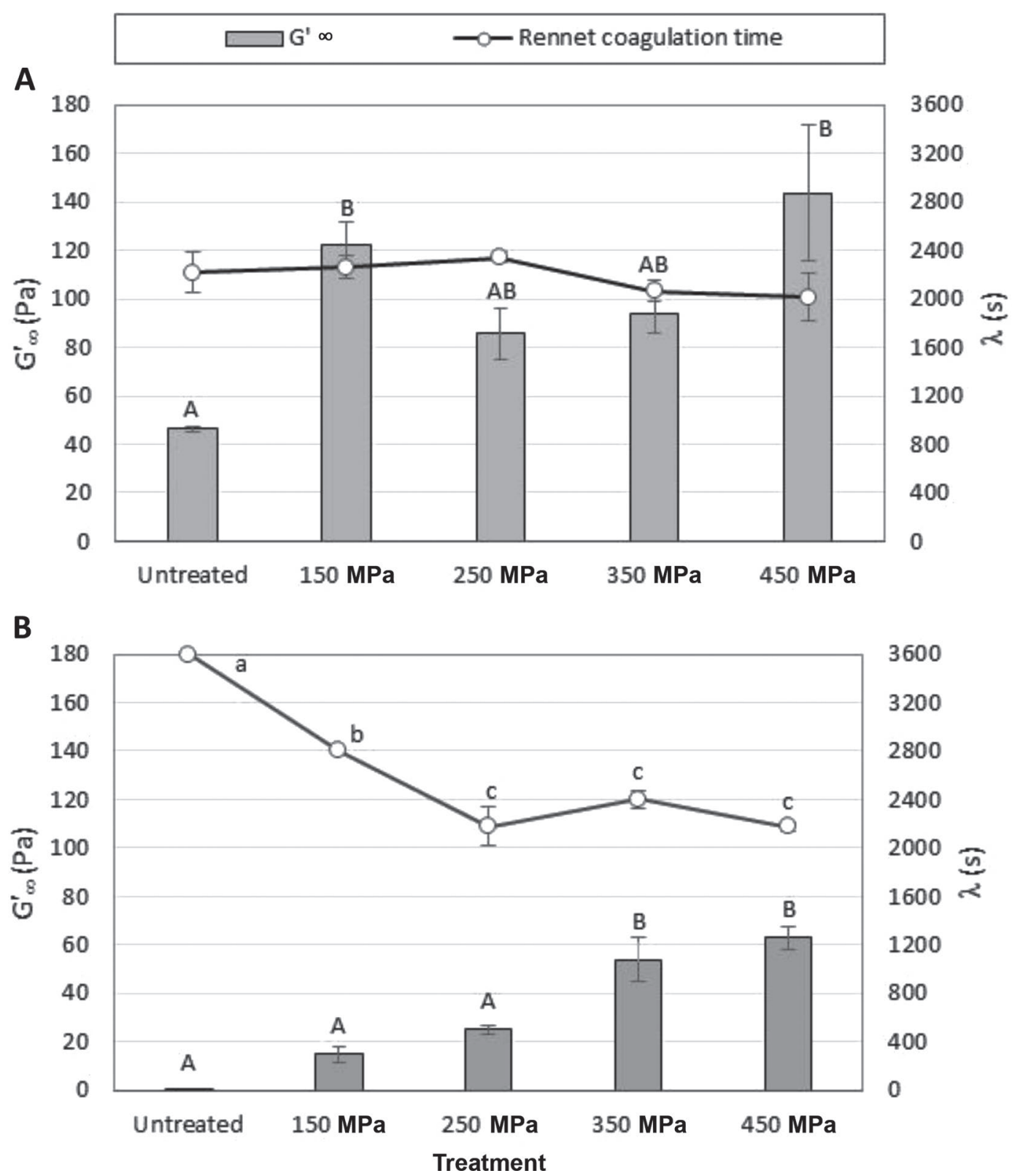

Figure 6. Limiting gel firmness $\left(G_{\infty}^{\prime}\right)$ after $60 \mathrm{~min}$ and rennet coagulation time $(\lambda)$ in pre-sheared and renneted (A) $10 \%$ micellar casein concentrates (MCC), and (B) 10\% milk protein concentrates (MPC). Results are the average of 5 independent experiments for the treated samples and 3 for controls. Error bars represent the SEM. Data points not connected by the same letter are significantly different from each other $(P<0.05)$. All samples were subjected to shear mixing before the addition of rennet. 
Table 3. Concentration of $\mathrm{Ca}^{2+}$ in $10 \%$ micellar casein concentrate (MCC) and $10 \%$ milk protein concentrate (MPC) samples, before and after high-pressure processing (HPP) treatment

\begin{tabular}{|c|c|c|c|}
\hline Treatment & $\begin{array}{c}\mathrm{Ca}^{2+} \text { concentration for } \\
10 \% \mathrm{MCC}^{1}(\mathrm{~m} M)\end{array}$ & $\begin{array}{c}\mathrm{Ca}^{2+} \text { concentration for } \\
10 \% \mathrm{MPC}^{1}(\mathrm{~m} M)\end{array}$ & $\begin{array}{l}10 \% \text { MCC and } 10 \% \text { MPC } \\
\text { statistically different? }(P<0.05)\end{array}$ \\
\hline Untreated (control) & $4.95 \pm 0.08$ & $4.27 \pm 0.44$ & Yes \\
\hline $350 \mathrm{MPa}$ & $5.18 \pm 0.23$ & $4.44 \pm 0.11$ & Yes \\
\hline $450 \mathrm{MPa}$ & $4.85 \pm 0.25$ & $4.54 \pm 0.39$ & No \\
\hline
\end{tabular}

${ }^{1}$ Within the same type of sample $(10 \% \mathrm{MCC}$ or $10 \% \mathrm{MPC}), \mathrm{Ca}^{2+}$ levels were not significantly different from each other for the different treatment levels $(P>0.05)$.

(Figure 6). In 10\% MPC, pressurization up to $250 \mathrm{MPa}$ resulted in significant decreases in $\lambda$, after which a plateau was reached.

It should be noted that untreated MPC did not fully coagulate and particle size barely increased for this sample, and only after about $60 \mathrm{~min}$ after the addition of rennet. Additionally, the network strength for the renneted $10 \% \mathrm{MPC}$ was much lower than for the renneted 10\% MCC, at all treatment levels (Figure 5). This can be attributed to (1) a slightly lower casein concentration in the MPC samples compared with MCC; and (2) lower total calcium (Table 1) and free ionic calcium (Table 3) in MPC compared with MCC. The concentration of calcium ions is known to play a critical role in the nonenzymatic stage of milk coagulation (De Baun et al., 1953).

\section{HPP-Induced Changes in Proteins and Minerals}

Conformational changes of proteins in MPC and MCC were investigated using ATR-FTIR, a well-established method that can probe the secondary structure of proteins, as well as protein unfolding and aggregation (Dong et al., 2000; Carbonaro and Nucara, 2010). The protein and mineral profile of the soluble phase of HPP-treated MCC and MPC samples were used as an indication for pressure-induced dissociation or structural reconfiguration of proteins (or both).

Changes in Protein Secondary Structures. The FTIR spectra for untreated and HPP-treated MCC and MPC, as well as a negative control spectrum for mild and a positive control spectrum for severely heated skim milk are shown in Figure 7 . The range of 1,600 to $1,700 \mathrm{~cm}^{-1}$ was selected from the entire range evaluated, as this particular range has been associated with protein secondary structures. All spectra contained multiple component bands, representing $\alpha$-helices, $\beta$-sheets, turns, and random structures, identified according to Kong and $\mathrm{Yu}$ (2007). Identification of these bands and the interpretation of all observed changes, based on existing literature, are summarized in Table
4. Below, only some of the most pronounced changes will be discussed.

Significant changes were observed in the bands assigned to various secondary structures in severely heated milk as compared with the mildly heated (HTST) milk. Most of the observed changes are likely due to the heat sensitive serum proteins. However, because spectra in Figure 7 represent a cumulative picture of the secondary structures in heterogeneous protein systems, we will not attempt to assign the observed changes in intensity to individual proteins, but rather assess these changes globally. For the skim milk heat treated at more than $90^{\circ} \mathrm{C}$ for $5 \mathrm{~min}$, the bands centered around 1,630 and $1,642 \mathrm{~cm}^{-1}$, typically associated with $\beta$-sheets (Lee et al., 2007; O'Loughlin et al., 2015), decrease in intensity, whereas a new peak centered around $1,652 \mathrm{~cm}^{-1}$ appeared, which has been associated with $\alpha$-helixes (Ye et al., 2017). Additionally, new peaks appeared in the spectral range 1,681 to $1,685 \mathrm{~cm}^{-1}$, which have been attributed before to thermally induced intermolecular $\beta$-sheet aggregates (Dong et al., 1997, 2000). The high heat treatment also resulted in new features in the spectral range 1,697 to $1,699 \mathrm{~cm}^{-1}$, which Kong and $\mathrm{Yu}$ (2007) attributed to new $\beta$-sheet structures.

The FTIR spectra for untreated 10\% MCC and $10 \%$ MPC were similar to that of the severely heated milk, indicating that some level of denaturation occurred during the manufacture of the protein powders. The more pronounced peaks for the protein concentrates compared with milk is due to the higher protein concentration in the latter. Also, a comparison of the intensity of the peaks for the 2 protein preparations indicates higher degree of denaturation in untreated MCC compared with untreated MPC. What is remarkable is that similar changes in band intensity were induced by HPP compared with heat treatment. These changes were accentuated by HPP treatment, with pressures above 250 $\mathrm{MPa}$ inducing similar changes as in the severely heat treated milk, for both 10\% MCC (Figure 7A) and 10\% MPC (Figure 7B). The gradual effect of pressure was more pronounced for 10\% MPC, which had a lower 
degree of denaturation before the HPP treatment compared with $10 \%$ MCC.

Proteomic Evaluation of the Soluble Phase. The proteomic profiles of the soluble phase of MCC and MPC showed some pressure-induced changes, which were affected both by the total protein concentration and the presence of serum proteins (Figure 8). In all samples, levels of soluble $\alpha_{\mathrm{S}^{-}}$and $\alpha_{\mathrm{S} 2^{-}}$-casein increased with pressure treatment up to $250 \mathrm{MPa}$, after which they levelled off; soluble $\alpha_{S_{2}}$-casein levels increased more than all other proteins, which is in agreement with data reported previously for skim milk (Anema et al., 2005b). Soluble $\beta$-casein and $\kappa$-casein were mostly unchanged by pressure in all samples, though a slight decrease for both proteins were observed after treatment at $450 \mathrm{MPa}$.

Changes in serum protein levels $(\beta-\mathrm{LG}, \alpha-\mathrm{LA}$, and BSA) in the soluble phase were also monitored. In
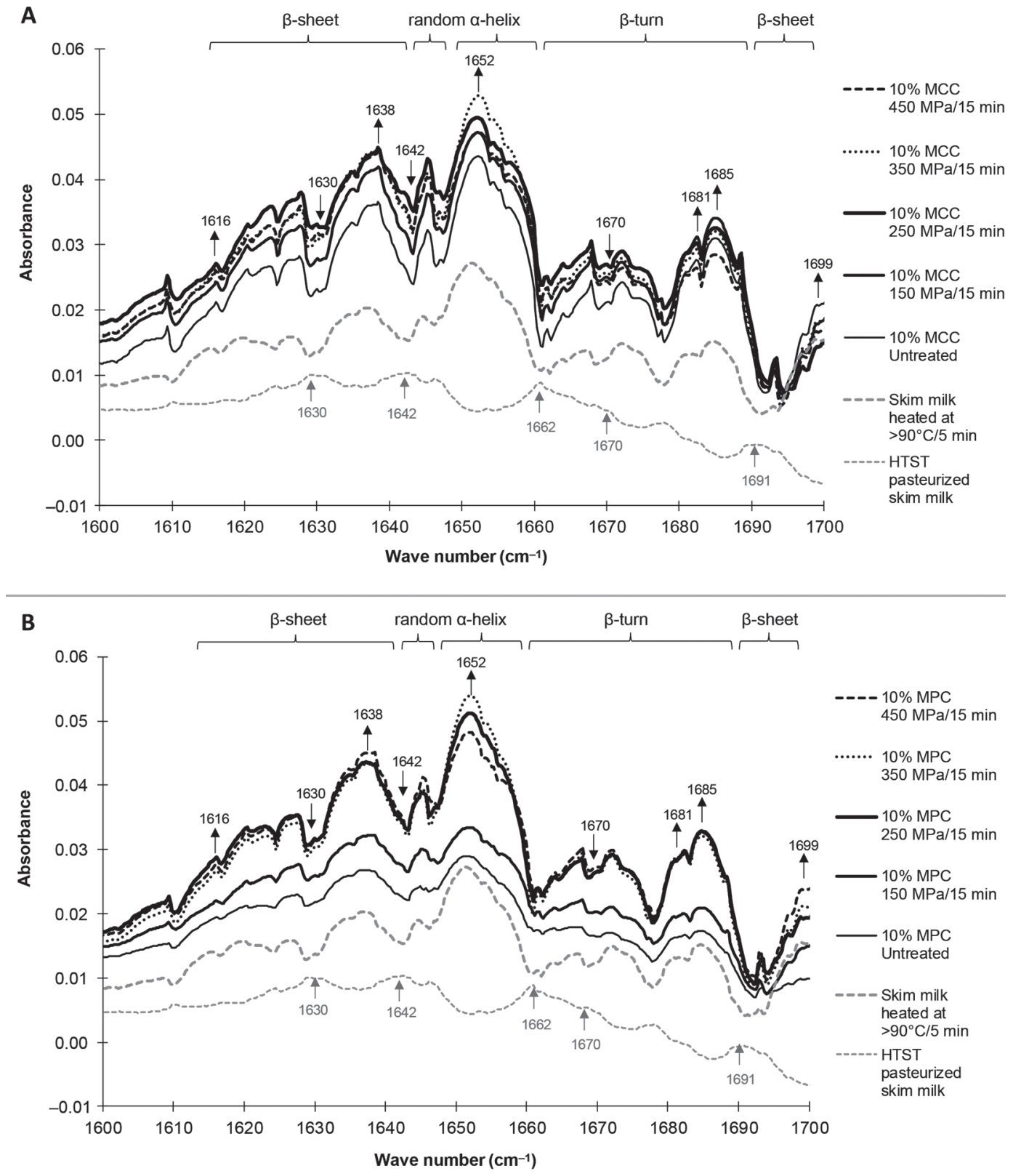

Figure 7. Attenuated total reflectance Fourier transform infrared spectra for $10 \%$ micellar casein concentrates (MCC; A) and 10\% milk protein concentrates (MPC; B) before (untreated) and after high-pressure processing treatment. Negative control: HTST pasteurized skim milk. Positive control: skim milk subjected to heating at $>90^{\circ} \mathrm{C}$ for 5 min. Identification of spectral regions for various conformations $(\beta$-sheet, $\alpha$-helix, random, and $\beta$-turn) was done according to Kong and Yu (2007). 
Table 4. Interpretation of the features in attenuated total reflectance Fourier transformed infrared spectroscopy (ATR-FTIR) in Figure $7^{1}$

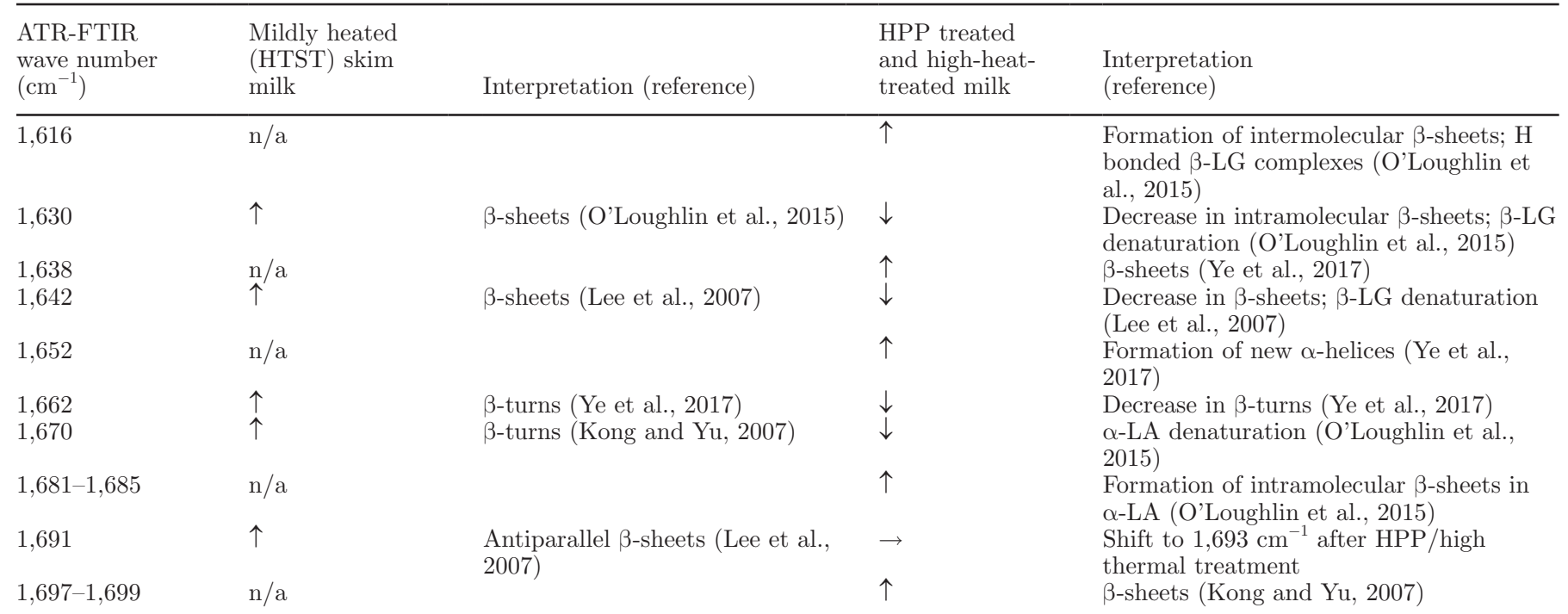

$\overline{1 \uparrow}=$ positive peak/increase in band intensity; $\downarrow=$ negative peak/decrease in band intensity; $\rightarrow=$ peak shift; n/a $=$ not applicable; HPP $=$ high-pressure processing.
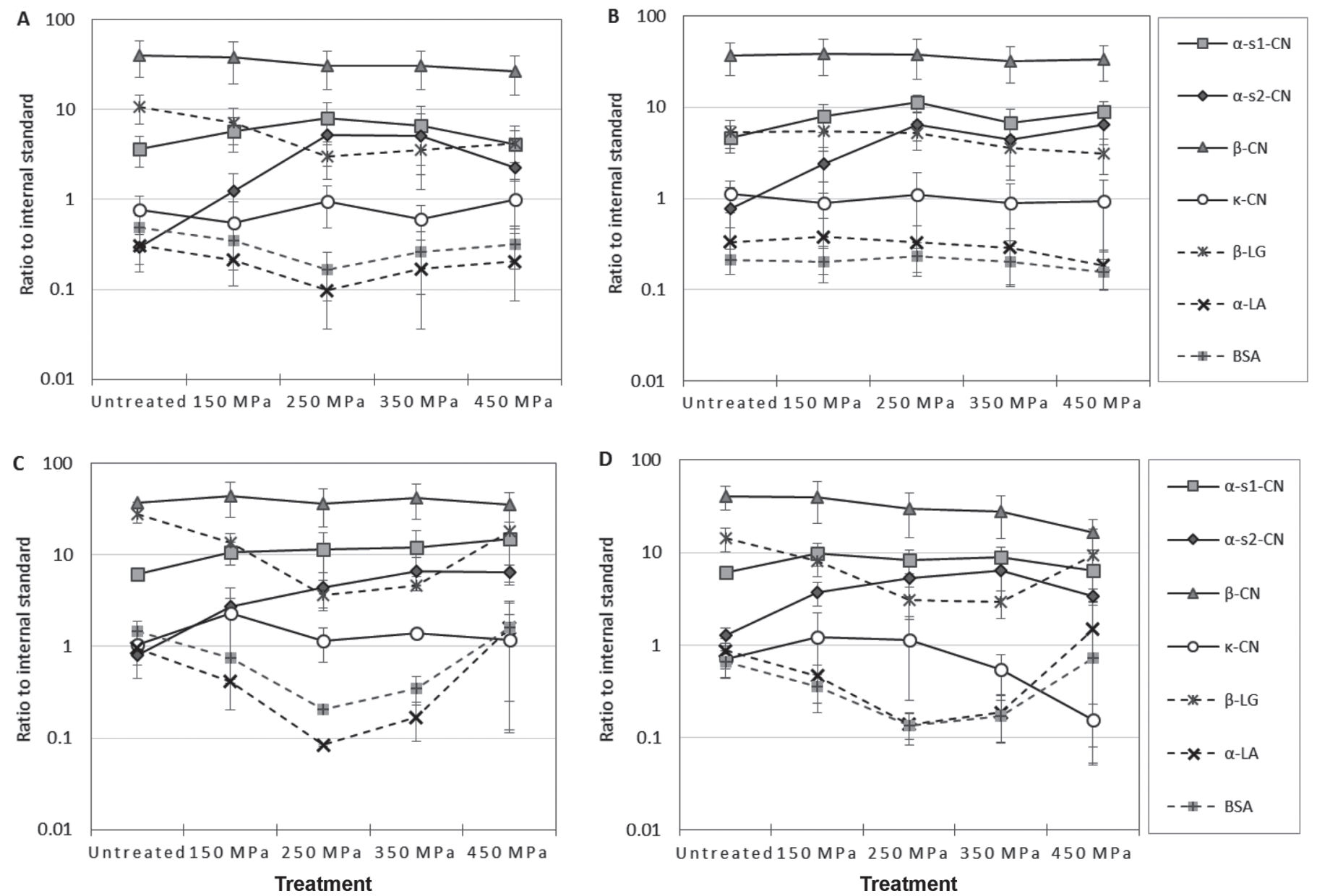

Figure 8. Soluble protein levels compared with an internal standard (apomyoglobin) in (A) 2.5\% micellar casein concentrates (MCC), (B) $2.5 \%$ milk protein concentrates (MPC), (C) 10\% MCC, and (D) 10\% MPC. Data points represent averages of triplicate independent experiments, with the exception of $10 \%$ MCC, for which only 2 independent replicates were available. Error bars represent the SEM. 

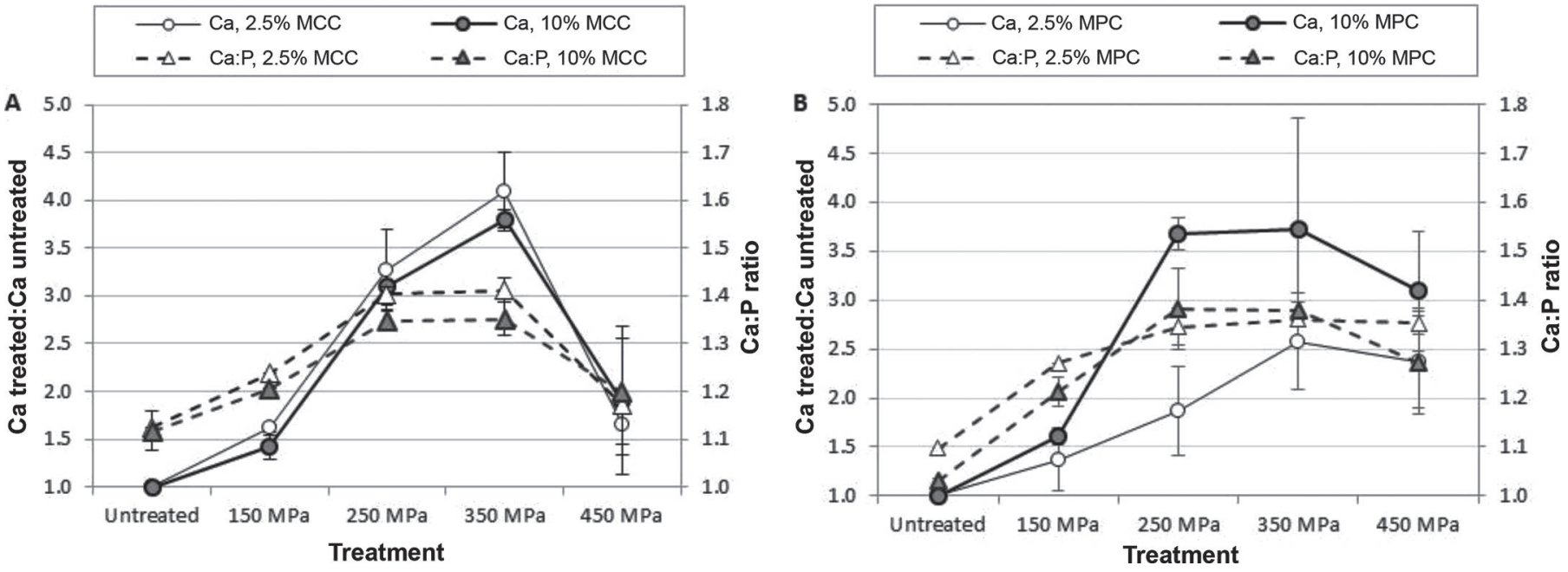

Figure 9. Change in soluble Ca and Ca:P ratio with pressure treatment in (A) micellar casein concentrates (MCC) and (B) milk protein concentrates (MPC). Results are the average of 4 independent experiments. Error bars represent the SEM.

the $2.5 \% \mathrm{MCC}$ and $2.5 \% \mathrm{MPC}$ samples, the levels of soluble serum proteins decreased slightly with pressure treatment. In $2.5 \%$ MCC pressurization led to small but significant decreases in soluble $\beta-\mathrm{LG}$ as pressure level increased, although no significant differences were observed among treatments above $250 \mathrm{MPa}$. However, for the 10\% MCC and 10\% MPC samples, an interesting trend was observed, which was consistent across $\beta-\mathrm{LG}, \alpha-\mathrm{LA}$, and BSA. The serum protein levels in the soluble phase decreased compared with the untreated samples with pressurization up to $250 \mathrm{MPa}$, and then increased with pressure level. This trend was rather surprising, especially considering that $\alpha$-LA does not readily denature at pressures below $500 \mathrm{MPa}$, whereas both BSA and $\beta-\mathrm{LG}$ are pressure sensitive (Patel et al., 2006).

Soluble Minerals in HPP-Treated MCC and $M P C$. Pressure induced significant changes in the solubility of minerals associated with the casein micelle ( $\mathrm{Ca}, \mathrm{P}$, and $\mathrm{Mg}$ ), and only minimal changes in minerals typically found in the aqueous phase ( $\mathrm{Na}$ and $\mathrm{K})$. This discussion will focus only on $\mathrm{Ca}$ and $\mathrm{P}$, the minerals that are most relevant to the casein micelle structure. Figure 9 shows changes in the levels of soluble $\mathrm{Ca}$ (solid lines) and in the Ca:P ratio (dashed lines) for MCC (Figure 9A) and MPC (Figure 9B), respectively. For all samples, levels of soluble $\mathrm{Ca}$ and $\mathrm{P}$ increased after pressure treatment up to $350 \mathrm{MPa}$, and then decreased after pressurization at $450 \mathrm{MPa}$. In $\mathrm{MCC}$, the trend was very similar for either 2.5 or $10 \%$ concentration, whereas for MPC the increase in soluble Ca was less pronounced in $2.5 \%$ samples compared with the $10 \%$ samples (Figure 9B). The Ca:P followed a similar trend as soluble $\mathrm{Ca}$, increasing with pressures up to $350 \mathrm{MPa}$, then decreased slightly after $450 \mathrm{MPa}$ treatment, but remained still higher than the control. In MCC, the $\mathrm{Ca}: \mathrm{P}$ ratio at $450 \mathrm{MPa}$ was significantly lower $(P<$ 0.05) compared with the $350 \mathrm{MPa}$ treatment. In MPC, the $\mathrm{Ca}: \mathrm{P}$ ratio after $450 \mathrm{MPa}$ treatment was slightly lower, but not significantly different than after the 350 $\mathrm{MPa}$ treatment. Changes in Ca:P ratios were very similar at both concentrations. Phosphorus and magnesium levels (data not shown) followed a similar pattern as calcium, for all protein preparations.

\section{DISCUSSION}

Pressure treatment of MCC and MPC at $2.5 \%$ casein concentration caused disintegration of casein micelles, at a level proportional to the pressure level. At $10 \%$ casein concentration, casein micelle disintegration took place up to $250 \mathrm{MPa}$, whereas pressures above $350 \mathrm{MPa}$ induced aggregation and the formation of a weak gel network, particularly for MCC. It has been reported before that pressurization and rapid depressurization in systems with high concentrations of casein can induce gelation (Kumeno et al., 1994; Keenan et al., 2001; Merel-Rausch et al., 2007). In this work, gelation was clearly observed in samples treated at $450 \mathrm{MPa}$, which also had the highest depressurization of all pressure treatments $(84.4 \pm 7.7 \mathrm{MPa} / \mathrm{s})$. According to MerelRausch et al. (2007), this depressurization rate is just sufficient to induce gelation at $10 \%$ casein concentration, which is slightly higher than the casein levels used in this study.

The pressure-induced micelle destabilization is also supported by the similarity between the trends in the levels of soluble calcium and soluble calcium binding 


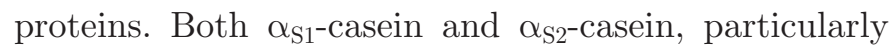
the latter, have a high degree of phosphorylation and a strong propensity to bind calcium, which is very important for casein micelle stability (Farrell, 1999). The increase in $\alpha_{\mathrm{S} 1}$-casein and $\alpha_{\mathrm{S} 2}$-casein, along with $\mathrm{Ca}$, in the aqueous phase following pressure treatment up to $350 \mathrm{MPa}$ suggests that they have migrated together out of the casein micelles during pressurization. After treatment at $450 \mathrm{MPa}$, the decrease in soluble $\alpha_{\mathrm{S}_{1}}$-casein, $\alpha_{\mathrm{S} 2_{2}}$-casein, and Ca suggests their re-association into insoluble complexes. This is consistent with the findings of Regnault et al. (2006), who showed that calcium released from casein micelles after pressure treatment of skim milk binds to soluble proteins.

The changes in the Ca:P ratio also offers some interesting insight into the redistribution of minerals between the micelle and the aqueous phase. The value of $\mathrm{Ca}: \mathrm{P}$ in the untreated protein concentrates was about 1.1, which is consistent with the values for untreated MCC reported by Beliciu et al. (2012) and with the Ca:P ratio of micellar calcium phosphate reported by Gaucheron (2005). After pressure treatment, these values increased to a maximum of about 1.4 for the 350 MPa treatment, for all protein concentrates. Based on the discussion on different forms of calcium phosphate in milk by Gaucheron (2005), this suggests the dissociation of tricalcium phosphate $(\mathrm{Ca}: \mathrm{P}=1.5)$ from the phosphoserine residues in the casein structure as a result of pressure treatment and its migration into the soluble phase. This dissociation of tricalcium phosphate would facilitate the destabilization and disintegration of casein micelles.

The renneting behavior is also indicative of changes in protein structure after HPP treatment. The changes in renneting kinetics of the 10\% MCC and 10\% MPC after pressure treatment clearly indicated some pressure induced structural changes in the casein micelle. The reasons for the inability of untreated MPC to coagulate are not clear, but may be due to a combination of (1) denaturation of serum proteins and formation of $\kappa$-casein-serum protein complexes, which would affect the enzymatic stage of renneting; and (2) insufficient $\mathrm{Ca}^{2+}$ concentration $(4.27 \pm 0.44 \mathrm{mM}$ in $10 \% \mathrm{MPC}$ compared with $4.95 \pm 0.08 \mathrm{mM}$ in $10 \% \mathrm{MCC}$ ), which interfered with the network formation stage of renneting. These differences might also explain the overall differences in renneting behavior between MCC and MPC. In MCC, pressurization resulted in increased network firmness after renneting, although the network formation time was not strongly affected by pressure. For MPC, the network formation time decreased and the network firmness increased after pressure treatment of up to $350 \mathrm{MPa}$, and reached a plateau after that. In
HPP-treated skim milk, $\beta$-LG was reported to denature at pressures above $250 \mathrm{MPa}$ and form complexes with $\kappa$-casein through disulfide bond exchange (Patel et al., 2006; Anema, 2010), which was found to inhibit the action of rennet by blocking substrate access (Zobrist et al., 2005). At higher pressures, around $400 \mathrm{MPa}$, Patel et al. (2006) have shown that $\beta$-LG aggregates both with $\kappa$-casein and $\alpha_{S 2}$-casein. Yet, the different trends in soluble $\beta$-LG, $\kappa$-casein, and $\alpha_{\mathrm{S}^{2}}$-casein observed in this study (Figure 7) do not suggest the formation of such associations. Instead, as suggested by the FTIR data (Figure 8), serum proteins in 10\% MPC and $10 \%$ MCC samples treated at the higher pressure levels (350 $\mathrm{MPa}$ and $450 \mathrm{MPa}$ ) become extensively denatured and form intermolecular aggregates, which would also explain the reduced level of $\beta-\mathrm{LG}, \alpha-\mathrm{LA}$, and BSA in the soluble phase shown in Figure 8.

Changes in casein micelle structure are visually confirmed by the scanning electron microscopy images. The micrographs in Figures 2 and 3 show small, spherical substructures of 15 to $20 \mathrm{~nm}$ in diameter, which appear to be the building units of the micelle structure for the untreated controls. After treatment at $450 \mathrm{MPa}$, the small substructures are no longer associated as micelles, and form a homogeneous network structure (Figures 2C and 3B).

Overall, the data presented here suggests that pressure treatment of high-concentration milk protein concentrates (MCC and MPC) leads to similar pressure-induced changes as in milk. Casein micelles are particularly affected, in a 2-step process: (1) dissociation of micelles into substructures under pressure, and (2) re-aggregation of these substructures upon pressure release (Merel-Rausch et al., 2007). The extent of dissociation and re-aggregation depends on the pressure level. At $150 \mathrm{MPa}$, some disruption of micelles occurs, which is limited to dissociation and release of the smaller substructures from the casein micelles. At 250 to 350 $\mathrm{MPa}$, a transition point is reached, and pressure treatment significantly loosens the micelle structure. It has been reported before that micelle dissociation in milk is complete at around $300 \mathrm{MPa}$ (Gebhardt et al., 2005; Orlien et al., 2006), but in concentrated systems this is shifted to higher pressure levels because less solvent is available to solubilize the colloidal calcium phosphate (Huppertz and De Kruif, 2006). Treatment at pressures above $350 \mathrm{MPa}$ resulted in re-aggregation of the casein substructures into a tightly knit homogeneous network, which macroscopically has the characteristics of a weak physical gel. Serum proteins were denatured by pressure treatment, and likely participated in the formation of intermolecular aggregates after pressure treatments above $350 \mathrm{MPa}$. 


\section{CONCLUSIONS}

This research examined structural changes occurring in dilute $(2.5 \%)$ and concentrated (10\%) MCC and MPC as a result of low temperature pressure treatment at pressures of up to $450 \mathrm{MPa}$. Rennet coagulation kinetics, particle size, as well as soluble mineral and protein levels, were altered by pressure treatment, and the observed changes were pressure, concentration, and composition dependent. From a practical perspective the pressure-induced changes observed here can be used as a basis for the development of new food products, ranging from clear or translucent casein-fortified beverages, to soft physical gels with high protein content. Of particular interest are the changes that occur in high protein concentration systems $(10 \%)$, for which pressurization induced gelation without acidification or the use of heat. This could be very attractive, particularly because HPP treatment under the gel-forming conditions observed here is known to inactivate a range of foodborne pathogens (Viazis et al., 2008; Chawla et al., 2011), and therefore such a treatment could be used as a dual structure formation and cold pasteurization step.

\section{ACKNOWLEDGMENTS}

The authors acknowledge the financial support for this study from the New York State Milk Promotion Advisory Board and USDA-National Institute of Food and Agriculture (Washington, DC; grant 2016-6701724635). We also thank Noopur Gosavi and José Maldonado from Rutgers University (New Brunswick, NJ) for their kind assistance in performing the HPP treatments; Shaun Sim, Linran Wang, Yifan Cheng, Joice Pranata, Jiahui Jian, and Huijie Feng from Cornell University (Ithaca, NY) for their support with sample analyses; and Robert Sherwood from the Cornell Proteomics Facility for his technical assistance with the protein analyses.

\section{REFERENCES}

Anema, S. G. 2010. Effect of pH at pressure treatment on the acid gelation of skim milk. Innov. Food Sci. Emerg. Technol. 11:265-273.

Anema, S. G., S. Lauber, S. K. Lee, T. Henle, and H. Klostermeyer. 2005a. Rheological properties of acid gels prepared from pressure- and transglutaminase-treated skim milk. Food Hydrocoll. 19:879-887.

Anema, S. G., E. K. Lowe, and R. Stockmann. 2005b. Particle size changes and casein solubilisation in high-pressure-treated skim milk. Food Hydrocoll. 19:257-267.

AOAC International. 2010a. AOAC Official Method 989.05. Fat in Milk-Modified Mojonnier Ether Extract. Official Methods of Analysis (17th). AOAC International, Gaithersburg, MD.

AOAC International. 2010b. AOAC Official Method 991.20. Nitrogen (Total) in Milk. Official Methods of Analysis (17th). AOAC International, Gaithersburg, MD.
AOAC International. 2010c. AOAC Official Method 998.05. Noncasein Nitrogen Content of Milk Kjeldahl Method. Official Methods of Analysis (17th). AOAC International, Gaithersburg, MD.

AOAC International. 2010d. AOAC Official Method 927.05. Moisture in Dried Milk. Official Methods of Analysis (17th). AOAC International, Gaithersburg, MD.

Beliciu, C. M., A. Sauer, and C. I. Moraru. 2012. The effect of commercial sterilization regimens on micellar casein concentrates. J. Dairy Sci. 95:5510-5526.

Carbonaro, M., and A. Nucara. 2010. Secondary structure of food proteins by Fourier transform spectroscopy in the mid-infrared region. Amino Acids 38:679-690.

Chawla, R., G. R. Patil, and A. K. Singh. 2011. High hydrostatic pressure technology in dairy processing: A review. J. Food Sci. Technol. 48:260-268.

Considine, T., H. A. Patel, S. G. Anema, H. Singh, and L. K. Creamer. 2007. Interactions of milk proteins during heat and high hydrostatic pressure treatments-A review. Innov. Food Sci. Emerg. Technol. 8:1-23.

De Baun, R. M., W. M. Connors, and R. A. Sullivan. 1953. The preparation of crystalline rennin and a study of some of its properties. Arch. Biochem. Biophys. 43:324-338.

Dong, A., B. Kendrick, L. Kreilgard, J. Matsuura, M. C. Manning, and J. F. Carpenter. 1997. Spectroscopic study of secondary structure and thermal denaturation of recombinant human factor XIII in aqueous solution. Arch. Biochem. Biophys. 347:213-220.

Dong, A., T. W. Randolph, and J. F. Carpenter. 2000. Entrapping intermediates of thermal aggregation in $\alpha$-helical proteins with low concentration of guanidine hydrochloride. J. Biol. Chem. 275:27689-27693.

Farrell, H. M. 1999. Physical equilibria: Proteins. Pages 461-510 in Fundamentals of Dairy Chemistry. N. P. Wong, R. Jenness, M. Keeney, and E. H. Marth, ed. Aspen Publishers Inc., Gaithersburg, MD

Gaucheron, F. 2005. The minerals of milk. Reprod. Nutr. Dev. 45:473483.

Gaucheron, F., M. H. Famelart, F. Mariette, K. Raulot, F. Michel, and Y. Le Graetf. 1997. Combined effects of temperature and highpressure treatments on physicochemical characteristics of skim milk. Food Chem. 59:439-447.

Gebhardt, R., W. Doster, and U. Kulozik. 2005. Pressure-induced dissociation of casein micelles: Size distribution and effect of temperature. Braz. J. Med. Biol. Res. 38:1209-1214.

Huppertz, T., P. F. Fox, and A. L. Kelly. 2003. High pressure-induced changes in the creaming properties of bovine milk. Innov. Food Sci. Emerg. Technol. 4:349-359.

Huppertz, T., and C. G. De Kruif. 2006. Disruption and reassociation of casein micelles under high pressure: Influence of milk serum composition and casein micelle concentration. J. Agric. Food Chem. 54:5903-5909.

Keenan, R. D., D. J. Young, C. M. Tier, A. D. Jones, and J. Underdown. 2001. Mechanism of pressure-induced gelation of milk. J. Agric. Food Chem. 49:3394-3402.

Kong, J., and S. Yu. 2007. Fourier transform infrared spectroscopic analysis of protein secondary structures. Acta Biochim. Biophys. Sin. (Shanghai) 39:549-559.

Kumeno, K., N. Nakahama, K. Honma, T. Kimura, and M. Watanbe. 1994. Gelation mechanism of pressure induced gel from freezeconcentrated milk. Nippon Shokuhin Kogyo Gakkaishi 41:335-338.

Lee, S. H., T. Lefèvre, M. Subirade, and P. Paquin. 2007. Changes and roles of secondary structures of whey protein for the formation of protein membrane at soy oil/water interface under high-pressure homogenization. J. Agric. Food Chem. 55:10924-10931.

Merel-Rausch, E., I. P. Duma, and J. Hinrichs. 2006. Pressure-induced modification of casein micelles - Influence of pressure built-up rate, pressure level, release rate, and temperature on viscosity and particle size. Milchwissenschaft 61:255-259.

Merel-Rausch, E., U. Kulozik, and J. Hinrichs. 2007. Influence of pressure release rate and protein concentration on the formation of pressure-induced casein structures. J. Dairy Res. 74:283-289. 
O'Callaghan, D. J. O., and T. P. Guinee. 1995. Comparison of mathematical models applied to the rennet coagulation of skim milks. J. Texture Stud. 26:607-633.

O'Loughlin, I. B., P. M. Kelly, B. A. Murray, R. J. FitzGerald, and A. Brodkorb. 2015. Concentrated whey protein ingredients: A Fourier transformed infrared spectroscopy investigation of thermally induced denaturation. Int. J. Dairy Technol. 68:349-356.

Orlien, V., J. C. Knudsen, M. Colon, and L. H. Skibsted. 2006. Dynamics of casein micelles in skim milk during and after high pressure treatment. Food Chem. 98:513-521.

Patel, H. A., H. Singh, S. G. Anema, and L. K. Creamer. 2006. Effects of heat and high hydrostatic pressure treatments on disulfide bonding interchanges among the proteins in skim milk. J. Agric. Food Chem. 54:3409-3420.

Regnault, S., E. Dumay, and J. C. Cheftel. 2006. Pressurisation of raw skim milk and of a dispersion of phosphocaseinate at $9^{\circ} \mathrm{C}$ or $20^{\circ} \mathrm{C}$ : Effects on the distribution of minerals and proteins between colloidal and soluble phases. J. Dairy Res. 73:91-100.
Sauer, A., and C. I. Moraru. 2012. Heat stability of micellar casein concentrate (MCC) as affected by temperature and $\mathrm{pH}$. J. Dairy Sci. 95:6339-6350.

Scott-Blair, G. W., and J. Burnett. 1963. An equation to describe the rate of setting of blood and milk. Biorheology 1:183-191.

Steffe, J. F. 1996. Viscoelasticity. Pages 294-350 in Rheological Methods in Food Process Engineering, 2nd ed. Freeman Press, East Lansing, MI.

Viazis, S., B. E. Farkas, and L. A. Jaykus. 2008. Inactivation of bacterial pathogens in human milk by high-pressure processing. J. Food Prot. 71:109-118.

Ye, M. P., R. Zhou, Y. R. Shi, H. C. Chen, and Y. Du. 2017. Effects of heating on the secondary structure of proteins in milk powders using mid-infrared spectroscopy. J. Dairy Sci. 100:89-95.

Zobrist, M. R., T. Huppertz, T. Uniacke, P. F. Fox, and A. L. Kelly. 2005. High-pressure-induced changes in the rennet coagulation properties of bovine milk. Int. Dairy J. 15:655-662. 